\title{
STUDIES OF COPROPORPHYRIN. III. IDIOPATHIC COPROPORPHYRINURIA; A HITHERTO UNRECOGNIZED FORM CHARACTERIZED BY LACK OF SYMPTOMS IN SPITE OF THE EXCRETION OF LARGE AMOUNTS OF COPROPORPHYRIN ${ }^{1}$
}

\author{
By CECIL JAMES WATSON, SAMUEL SCHWARTZ, WILLIAM SCHULZE, \\ LEON O. JACOBSON, AND RALPH ZAGARIA
}

\author{
(From the Department of Medicine, University of Minnesota Hospital, Minneapolis, and the \\ Metallurgical Laboratory of the University of Chicago [now the \\ Argonne National Laboratory])
}

(Received for publication July 9, 1948)

It has been generally assumed that the formation and excretion of large amounts of coproporphyrin is regularly associated with the presence of symptoms, usually of either abdominal or nervous type. Certain students of the porphyrins, notably Carrié (1) have ascribed to coproporphyrin a primary rôle in the symptoms of lead poisoning and other conditions associated with a considerable increase of coproporphyrin excretion. Thus, the abdominal pain and peripheral neuritis are designated by Carrié as "porphyrinopathic" manifestations. Intermittent acute porphyria, characterized by production and excretion of the wholly abnormal Waldenström uro-type porphyrin, is often entirely latent and symptomless for long periods, probably, even, for the individual's entire life span in some instances. So far as can be determined, however, no case has been recorded in which there was a massive and persistent, and at the same time entirely symptomless idiopathic coproporphyrinuria. At least until further knowledge may indicate a different terminology, it is believed best to use this designation, rather than porphyria, for the cases which will be described. In agreement with Waldenström, we prefer to reserve the latter term for cases in which uroporphyrin, or porphyrins of uroporphyrin type, such as the Waldenström or 260 porphyrin $(2-4)$, are demonstrated. The term porphyria, in other words, connotes a metabolic error in which an entirely abnormal porphyrin is formed and excreted, while the term coproporphyrinuria is noncommittal in the sense that while it is both physio-

\footnotetext{
1 Aided by grants from the John and Mary R. Markle Foundation, the Rockefeller Foundation, and the Medical Research Fund of the Graduate School, University of Minnesota.
}

logical and pathological, secondary to a variety of disturbances, the possibility exists that occasional cases, such as those described in the following, are likewise "inborn errors of metabolism."

\section{CASE REPORTS}

Case 1. W. V. Q., J', 26, white, chemist. This individual had no complaints and considered himself to be in excellent health.

As a graduate student he had worked for one and a half years in a laboratory in which 1-2 pounds of mercury were always kept in an open vessel. He recalls "one or two" mercury spills in the course of his own work, in which he wiped up the mercury with copper powder. Once, during this same period, about two years prior to the present study, he was pipetting mercury and some entered his mouth, but he is certain that none of it was swallowed. Also about two years ago while pipetting saturated copper sulphate solution, some got into his mouth. He thought none was swallowed but he noted a "funny" feeling in the stomach for several hours. In addition to these episodes he has been exposed only to the usual organic and inorganic compounds found in most chemical laboratories. So far as could be determined alcoholic beverages were but rarely used and only in small amount.

As a child he had had measles, mumps and chicken pox, and pneumonia at 11 . His mother died of tuberculosis at 56, his father is living and well, as are three siblings. Neither the patient nor members of his family have ever noted red urine, and none have had suggestive complaints such as abdominal pain, severe constipation, or pain in the extremities. There has been nothing suggestive of light sensitivity in the patient or his relatives.

The physical, including the neurological examination was entirely normal. The blood pressure was 120/70. The routine examinations of the blood and urine were normal. There was no anemia. The blood smears revealed nothing abnormal; there was no increase in basophilic stipping. The sternal bone marrow was normal. The feces urobilinogen for three separate four-day periods was 83,86 , and $118 \mathrm{mgm}$./day; thus there was no evidence of an increase in rate of blood destruction, in fact, 
the values are rather low. There was no evidence of liver functional impairment. Thus the urine urobilinogen on three occasions was well within normal limits, $0.05,0.06$, and $0.12 \mathrm{mgm} . / 100 \mathrm{cc}$. The cephalin-cholesterol flocculation test was negative. Repeated serum bilirubin determinations were well within normal limits. The urine coproporphyrin was greatly increased as noted in Table I.

TABLE I

Urine coproporphyrin-case $W . V . Q$. and siblings

Case W. V. Q.

$$
\begin{gathered}
\text { Date } \\
4-24-45 \\
5-1-45 \\
5-22-45 \\
6-8-45 \\
6-16-45 \\
7-20-45 \\
9-18-45 \\
12-18-45 \\
1-23-46 \\
7-11-45 \\
7-28-45 \\
7-11-45 \\
9-20-45
\end{gathered}
$$

Sister M.

Brother Ru.
TABLE II

Fecal porphyrin concentration in case W.V.Q.

\begin{tabular}{c|c|c|c}
\hline \hline Date & Coproporphyrin & Protoporphyrin & Deuteroporphyrin \\
\cline { 2 - 4 } & $\gamma / 100 \mathrm{Gm}$. & $\gamma / 100 \mathrm{Gm} . *$ & $\gamma / 100 \mathrm{Gm} . *$ \\
$6-8-45$ & 69000 & 1263 & - \\
$9-21-45$ & 32375 & 381 & 638 \\
\hline
\end{tabular}

* The values for proto- and deuteroporphyrins are given in coproporphyrin equivalents.

The fecal porphyrins were quantitated on two occasions with results as given in Table II.

On several occasions the isomer distribution in the urine was determined by means of the differential precipitation method (6a). From 86-95\% coproporphyrin III was found. Coproporphyrin III methyl ester was repeatedly isolated in considerable amount from both feces and urine. The crystal habitus and dimorphic melting point were characteristic (8). The methods of isolation have been described elsewhere $(4,8,9)$.

Gastric and duodenal contents were examined, with the results shown in Table III.

The erythrocyte protoporphyrin was determined on two occasions by the method of Grinstein and Watson (10).

$$
\begin{array}{ll}
9-29-45 & 46 \gamma / 100 \text { cc. of cells } \\
3-24-46 & 37 \gamma / 100 \text { cc. of cells }
\end{array}
$$

On neither occasion was there any demonstrable coproporphyrin in either erythrocytes or plasma.

Examination of the bone marrow revealed a normal

\begin{tabular}{|c|c|c|c|c|c|c|}
\hline \multicolumn{2}{|c|}{ Time } & Source & Color & Fluorescence & Coproporphyrin & Bilirubin \\
\hline & $\begin{array}{l}11: 15 \text { a.m. } \\
11: 25 \text { a.m. }\end{array}$ & $\begin{array}{l}\text { Gastric } \\
\text { Gastric }\end{array}$ & $\begin{array}{l}\text { Nearly } \\
\text { colorless } \\
\text { Light brown }\end{array}$ & $\begin{array}{l}\text { Bluish } \\
\text { Medium red orange }\end{array}$ & $\begin{array}{r}\gamma / 100 c c . \\
0.6 \\
24.0\end{array}$ & $\begin{array}{c}m g . / 100 c c . \\
0 \\
\text { trace }\end{array}$ \\
\hline $\begin{array}{l}20 \mathrm{cc} . \\
35 \% \\
\mathrm{MgSO}\end{array}$ & $\begin{array}{l}11: 35 \text { a.m. } \\
11: 45 \text { a.m. } \\
11: 55 \text { a.m. }\end{array}$ & $\begin{array}{l}\text { Duodenal } \\
\text { Duodenal } \\
\text { Duodenal }\end{array}$ & $\begin{array}{l}\text { Brown } \\
\text { Golden brown } \\
\text { Golden brown }\end{array}$ & $\begin{array}{l}\text { Intense red orange } \\
\text { Intense red orange } \\
\text { Intense red orange }\end{array}$ & $\begin{array}{c}308.0 \\
720.0 \\
1327.0^{*}\end{array}$ & $\begin{array}{l}1.5 \\
4.4 \\
6.7\end{array}$ \\
\hline
\end{tabular}
morphology. The protoporphyrin concentration was $37 \gamma /$ 100 cc. No coproporphyrin was demonstrable.

Case 2. B. C., $\delta, 31$, negro laborer. Admitted to the Minneapolis General Hospital on January 23, 1948, with a diagnosis of diphtheria. A typical membrane was observed in the pharynx and throat cultures were positive for $B$. diphtheriae. The illness was not severe and there were no recognizable complications. 40,000 units of antitoxin were given on the day of admission. The patient made an uneventful recovery. The highest temperature recorded was $102^{\circ} \mathrm{F}$., on the day of admission. The temperature was consistently normal after the second hospital day.

TABLE III

Coproporphyrin concentration in gastric and duodenal contents

* $95 \%$ copro-III according to differential precipitation technique (6a). 
The urinary coproporphyrin was studied in this case because of the previous observations that diphtheria bacilli in broth cultures produce coproporphyrin in considerable amount (11). This has recently been shown to be the type III isomer (12). The present case was one of a group of diphtheria cases under investigation with respect to possible increases in UCP. It was surprising to find that this individual was excreting unusually large amounts of coproporphyrin, and that this greatly heightened excretion persisted long after the diphtheria had disappeared. There were no symptoms other than those related to the throat, of transitory nature. There was no history of exposure to chemicals or heavy metals, and the patient denied the use of alcoholic beverages in any form. There was no evidence of liver functional impairment. Thus the serum bilirubin was : $0.2 \mathrm{mgm} . / 100 \mathrm{cc}$. ( $1^{\prime}$ or prompt direct) and $0.9 \mathrm{mgm} . / 100 \mathrm{cc}$. total ; the cephalin cholesterol test was negative and the thymol turbidity 1.9 units; the serum alkaline phosphatase was 4.0 Bodansky units.

The patient was uncooperative and, although attempts were made to keep him under observation indefinitely, he left Minneapolis toward the end of April for an unknown destination.

The findings in this case were as follows:

TABLE IV

Urinary porphyrin excretion

\begin{tabular}{|c|c|c|c|c|c|}
\hline Date & UCP & $\begin{array}{c}\% \\
\text { type III } \\
\text { isomer }\end{array}$ & $\begin{array}{l}\text { M.P. of } \\
\text { cryst. } \\
\text { methyl } \\
\text { ester }\end{array}$ & $\begin{array}{l}\text { Porpho- } \\
\text { bilinogen } \\
\text { reaction } \\
\text { (5) }\end{array}$ & $\begin{array}{l}\text { Uropor- } \\
\text { phyrin }\end{array}$ \\
\hline $\begin{array}{l}1-25-48 \\
1-30-48 \\
2-5-48 \\
2-7-48 \\
2-8-48 \\
2-14-48 \\
2-16-48 \\
2-19-48 \\
2-20-48 \\
2-24-48 \\
2-25-48 \\
2-27-48 \\
3-3-48 \\
3-6-48 \\
4-20-48\end{array}$ & $\begin{array}{c}\gamma / 24 \text { hrs. } \\
8,674 \\
3,980 \\
2,000 \\
1,890 \\
1,610 \\
1,465 \\
3,062 \\
4,260 \\
3,780 \\
5,150 \\
6,468 \\
4,959 \\
6,177 \\
4,940 \\
206 \text { \% \% } \\
\text { (vol. } \\
\text { unknown) }\end{array}$ & $\begin{array}{r}99 \\
100 \\
98 \\
98\end{array}$ & $\begin{array}{l}130-1 \\
130\end{array}$ & $\begin{array}{l}\text { negative } \\
\text { negative } \\
\text { negative } \\
\text { negative } \\
\text { negative } \\
\text { negative } \\
\text { negative } \\
\text { negative }\end{array}$ & $\begin{array}{l}0 \\
0 \\
0 \\
0 \\
0\end{array}$ \\
\hline
\end{tabular}

Bile containing duodenal contents were obtained on 2-8-48. These exhibited intense red fluorescence and were found to have a coproporphyrin concentration of $128 \gamma / 100 \mathrm{cc}$. of which $82 \%$ was the type III isomer.

The erythrocyte protoporphyrin on $2-10-48$ was $36 \gamma$ / 100 cc. of cells. No porphyrin could be demonstrated in the plasma.

\section{DISCUSSION}

The two cases which have been described are of a type hitherto unrecognized. They are important
TABLE $\mathbf{V}$

Feces porphyrin findings

\begin{tabular}{c|c|c|c|c}
\hline \hline Date & $\begin{array}{c}\text { Copro- } \\
\text { porphyrin }\end{array}$ & $\begin{array}{c}\text { \% type III } \\
\text { isomer }\end{array}$ & $\begin{array}{c}\text { M.P. of cryst. } \\
\text { methyl ester }\end{array}$ & $\begin{array}{c}\text { Uropor- } \\
\text { phyrin }\end{array}$ \\
\cline { 2 - 3 } $2-10-48$ & $\begin{array}{c}\gamma / 100 \mathrm{Gm} . \\
32,800\end{array}$ & 90 & ${ }^{\circ} \mathrm{C}$. & \\
$2-15-48$ & 39,600 & 90 & $130-1^{\circ}$ & 0 \\
$2-16-48$ & 40,200 & - & - & 0 \\
\hline
\end{tabular}

from a number of standpoints, one of which was referred to in paper I of this series (7), which dealt with the normal coproporphyrin of the urine. It is evident that if an individual such as one of the two present cases contributed to a pool being collected from presumably normal individuals, as in Grotepass' study (13), the result would be affected to a very marked degree and would be interpreted erroneously. The complete lack of symptoms in these two individuals is of much interest since it casts considerable doubt on the belief that the symptoms of lead poisoning and porphyria are "porphyrinopathic," as Carrié and others have believed. In porphyria, of course, compounds other than coproporphyrin III may well be implicated, but in lead poisoning one finds only coproporphyrin III. It appears, however, that there is one striking difference between the present cases and cases of lead poisoning, in so far as porphyrin excretion is concerned. But slight or no increases of coproporphyrin III are encountered in the feces in lead poisoning ${ }^{8}$ even though relatively large amounts are present in the urine. In the present cases the amounts in the urine were considerably larger than those usually encountered in lead or other heavy metal poisoning, while the fecal coproporphyrin III was roughly ten times that of the urine. Thus it is evident that the total production of coproporphyrin in these two individuals is on a much larger scale than that of the secondary coproporphyrinurias of ordinary type. This would support the belief that the disturbance in the present cases represents an "inborn error of metabolism," albeit one that differs fundamentally from that of ordinary porphyria, in which uroporphyrin or uro-type porphyrins are also found.

In Table $\mathrm{V}$ it is noted that $90 \%$ of the fecal coproporphyrin was type III. This would indicate that $10 \%$, or from $3280-4020 y / 100 \mathrm{Gm}$., was

${ }^{3}$ At least in chronic cases. We have not had opportunity to study the fecal coproporphyrin in cases of acute plumbism. 
type I. This value would exceed the normal by approximately ten-fold. In the crystallization of the methyl ester, no evidence was observed for such an amount of copro-I as this figure would indicate. The isomer percentage values cannot be regarded as absolute, simply providing an approximation of the relative amounts of the two isomers. This is particularly true when either isomer constitutes more than $85 \%$ of the mixture $(6 \mathrm{~b})$. If the value had been $98-99 \%$ type III, as in the case of the urine, a normal amount of type $I$ isomer would have been indicated. As it is, a moderate increase cannot be excluded.

\section{SUMMARY AND CONCLUSIONS}

1. Two cases are described in which a great increase of coproporphyrin III excretion was unaccompanied by symptoms or signs of porphyria, metal or chemical poisoning or liver disease. The first case was that of a chemist who had had exposure to heavy metals and chemicals, of doubtful significance. The second was a negro laborer who suffered from mild diphtheria at the outset of the study, but whose heightened porphyrin excretion persisted for months after the diphtheria had disappeared.

2. Careful studies of several members of the family of the first case yielded no evidence of any disturbance of porphyrin metabolism. In the second case no other members of the family were available for study.

3. The duodenal contents in each instance contained large amounts of coproporphyrin III, presumably contributed by the bile. The feces contained corresponding increases, ranging from 32 to $69 \mathrm{mgm} . / 100 \mathrm{Gm}$., from 10 to 20 times the amount in the urine. It is empasized that this is quite unlike the ratio in chronic lead poisoning, in which considerably more coproporphyrin III is found in urine than in feces.

4. In neither case did the urine contain porphobilinogen or uro-type porphyrins.

5. The blood serum or plasma in the two instances was free of demonstrable porphyrin. The erythrocyte protoporphyrin was not significantly elevated in either case.

6. The general significance and probable constitutional nature of these cases is discussed.

\section{BIBLIOGRAPHY}

1. Carrié, C., Die Porphyrine. G. Thieme, Leipzig, 1936.

2. Waldenström, J., Studien über Porphyrie. Acta med. Scandinav., 1937, Supp. 82, p. 1.

3. Grinstein, M., Schwartz, S., and Watson, C. J., Studies of the uroporphyrins; the purification of uroporphyrin I and the nature of Waldenström's uroporphyrin, as isolated from porphyria material. J. Biol. Chem., 1945, 157, 323.

4. Watson, C. J., Schwartz, S., and Hawkinson, V., Studies of the uroporphyrins. II. Further studies of the porphyrins of the urine, feces, bile and liver in cases of porphyria, with particular reference to a Waldenström type porphyrin behaving as an entity on the Tswett column. J. Biol. Chem., 1945, $157,345$.

5. Watson, C. J., and Schwartz, S., A simple test for urinary porphobilinogen. Proc. Soc. Exp. Biol. \& Med., 1941, 47, 393.

6a. Schwartz, S., Hawkinson, V., Cohen, S., and Watson, C. J., A micromethod for the quantitative determination of the urinary coproporphyrin isomers (I and III). J. Biol. Chem., 1947, 168, 133.

b. Schwartz, S., Cohen, S., and Watson, C. J., A modified procedure for the quantitative determination of the urinary coproporphyrin isomers (I and III). United States Atomic Energy Commission Report MDDC 304, 1946. (Also in press in Plutonium Project Record.)

7. Watson, C. J., Hawkinson, V., Schwartz, S., and Sutherland, D., Studies of coproporphyrin. I. The per diem excretion and isomer distribution of coproporphyrin in normal human urine. J. Clin. Invest., $1949,28,447$.

8. Fischer, H., and Orth, H., Die Chemie des Pyrrols. Akadem. Verlagsgesellsch., 1937, Leipzig, Bd. II, 1 Hälfte.

9a. Watson, C. J., Concerning the naturally occurring porphyrins I. The isolation of coproporphyrin I from the urine in a case of cincophen cirrhosis. J. Clin. Invest., 1935, 14, 106.

b. IV. The urinary porphyrin in lead poisoning as contrasted with that excreted normally and in other diseases. Ibid., 1936, 15, 327.

10. Grinstein, M., and Watson, C. J., Studies of protoporphyrin. III. Photoelectric and fluorophotometric methods for the quantitative determination of the protoporphyrin in blood. J. Biol. Chem., 1943, $147,675$.

11. Coulter, C. B., and Stone, F. M., The occurrence of porphyrins in cultures of $C$. diphtheriae. J. Gen. Physiol., 1930, 14, 583.

12. Gray, C. H., and Holt, L. B., The porphyrin produced by diphtheria bacillus. J. Biol. Chem., 1947, 169, 235.

13. Grotepass, W., Zur Kenntnis der Natürlichen Harnporphyrine. Ztschr. f. Physiol. Chem., 1938, 253, 276. 